\title{
Iceland's Economic Crash and Integration Takeoff: An End to European Union Scepticism?
}

\author{
Baldur Thorhallsson* and Christian Rebhan
}

\begin{abstract}
Iceland's application for European Union (EU) membership in summer 2009 suggests that the country's political parties had reconsidered their longstanding scepticism towards European integration and opted for closer engagement with the EU after the financial crisis. Applying Moravcsik's liberal theory of preference formation, this article investigates the European policies of Iceland's political parties from 2007 to 2010, focusing on four related European issues which have been prominent in the Icelandic EU debate: an application to join the EU with no reservations; the unilateral adoption of the euro; the inclusion of a clause in the constitution allowing a transfer of sovereignty; and the holding of a referendum on an EU application. It analyses whether the economic crash actually led to a change in the political parties' economic preferences and to a subsequent reformulation and adaptation of their long-term European policy goals and, if not, then how Iceland's decision to apply for EU membership is to be understood. The article concludes that the parties' European policies have remained remarkably stable despite the EU application. This indicates that Iceland's EU membership application can only be understood through a thorough examination of domestic politics, to which liberal intergovernmentalism pays insufficient attention.
\end{abstract}

\section{The Financial Crisis and the European Union Membership Application}

Icelandic politicians have traditionally avoided the question of membership of the European Union (EU) or else taken a firm stance against it. The same can be said of the main interest groups, except for the Federation of Icelandic Industries (see detailed discussion in Thorhallsson 2004a, 2008). Iceland has, in fact, been the only country in Europe where the political elite has been relatively more sceptical towards European integration than has the electorate (Kristinsson \& Thorhallsson 2004). Nearly all Icelandic politicians were convinced that EU membership would place constraints on the country, particularly in the fisheries and agrarian sectors, rather than

* Baldur Thorhallsson, Faculty of Political Science, School of Social Science, University of Iceland, 101 Reykjavík, Iceland. E-mail: baldurt@hi.is 
provide benefits (Thorhallsson 2004c). Thus, Iceland only engaged within the framework of European integration in order to guarantee access to the European market and avoid the collapse of the Nordic Passport Union though membership of Schengen. The country also contradicted the predictions of small-state theory, according to which small states seek protection from large neighbours and international organisations in order to compensate for their economic vulnerability (Handel 1981). Iceland was even more exposed to the fortunes of the international economy than other small states due to the dramatic rise of the banking sector in the first decade of the twenty-first century. In 2007, the banking sector, for the first time, contributed more to gross domestic product (GDP) than the fishing industry (Statistics Iceland 2009) and had assets valued at over ten times Iceland's GDP (Central Bank of Iceland 2010a) in autumn 2008.

When the international financial crisis plunged Iceland into one of the worst economic collapses in recent history, the traditional reluctance of most of Iceland's political parties to engage with the European project came under increased scrutiny. The possibility that Iceland could nurture the resilient nature of its economy without the shelter of the formal EU institutional framework and without a more stable and reliable currency was called into question. Opinion polls showed that a clear majority of Iceland's population wanted to start membership negotiations with the EU, with an all-time high of 64 percent in favour of negotiations in February 2009 (Capacent Gallup 2009). The new left-wing government that came into power in May 2009 subsequently became the first government in Iceland to propose an EU application. This move represented a ground-breaking turnaround in the European policy of Icelandic governments, as is illustrated in Table 1, which traces their European policies back to 1988 when membership of the European Economic Area (EEA) first became an issue. On 16 July 2009, after a long and intense debate, the Icelandic parliament, the Althingi, passed a motion approving an EU membership application with a narrow majority of 33 to 28 votes and two abstentions (Parliamentary Records 2009a).

This relatively hasty membership application made it obvious that the economic crash had a profound (short-term) influence on the European policies of Iceland's political parties. It also provided a theoretical challenge to the various theories that tried to explain the longstanding reluctance of Iceland's political parties to advocate closer engagement in European integration up to that time. As Table 1 demonstrates, Iceland's European policy had evolved in only a short time span from a position of strong reluctance to apply for membership of the EU. However, no change had taken place in the stance of the traditional pillars of Iceland's EU scepticism that could account for this change. Fears concerning the 'unfavourable' Common Fisheries Policy (CFP) as well as the Common Agricultural Policy (CAP) of the 
(C) 2011 The Author(s)

Scandinavian Political Studies (C) 2011 Nordic Political Science Association

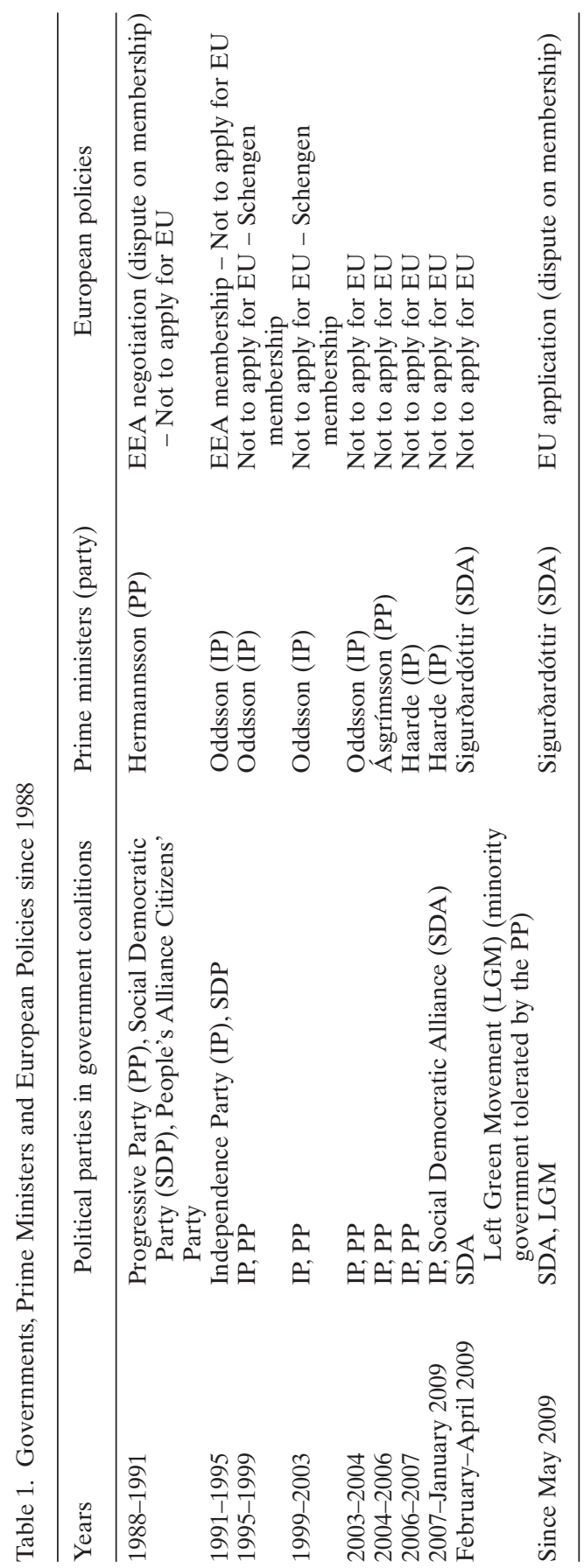


EU - which had been emphasised by liberal intergovernmentalists (Ingebritsen 1998) - remained the same. Constructivists and poststructuralists could not solve the puzzle either, as Icelanders still shared the same specific interpretation of their national sovereignty that made it hard for them to argue for EU membership in the political discourse (Hálfdanarson 2004, Bergmann Einarsson 2009). Apart from this, many specific characteristics of the Icelandic political system which had also been named as reasons for Iceland's exceptional EU scepticism were still in place, such as its politicians' belief in realism, the blocking power of the fishing industry, the over-representation of rural regions (where the dominant interests were those of fisheries and agriculture) in the Althingi, the lack of decisive policy making by the small national administration and the defence relationship with the United States (Thorhallsson 2004a).

Thus, while no one doubted the existence of a strong correlation between the economic crash and the EU membership application, continuity in the position of the main pillars of Iceland's EU scepticism raised serious doubts as to whether there had been any change at all in the European policies of the country's political parties.

\section{Liberal Intergovernmentalism and Iceland's European Policy}

Moravcsik's liberal theory of preference formation makes a strong case for the likelihood of a change in the European policies of Iceland's political parties. According to Moravcsik (1993, 1998), a country's European policy rests upon rational choices by national leaders who predominantly pursue economic interests - their own macro-economic preferences and the commercial interests of powerful economic producers in their states. Once national preferences have arisen out of domestic competition among economic interest groups, ruling parties and chief executives, states act on them externally as unitary and rational actors with a coherent national strategy. Thus, liberal intergovernmentalism could only make sense of Iceland's application for EU membership if the financial crisis had resulted in a change in macro-economic preferences within the government, visible through the election of a new pro-EU government or through adaptation of the ruling parties' European policies. Moreover, the theory also suggests that the commercial interests of powerful economic interest groups must have changed. This is something this article cannot explore in detail, but that will be accounted for in some measure since the interest groups' representation in the political party system and consultation with them in the formation of government policy have been identified as two powerful channels of indirect influence on foreign policy (Ingebritsen 1998). 
This article applies Moravcsik's liberal theory of preference formation to the European policies of Iceland's political parties from the general election in the spring of 2007 to the autumn of 2010, when the Althingi did not process motions calling for a withdrawal of the EU application and the holding of an immediate referendum on whether or not to continue the EU negotiations. It focuses, in particular, on the EU debate after the weakening of the Icelandic currency, the króna (ISK), in early 2008 and the economic crash in autumn of that year, leading to the general election in spring 2009 and the EU application three months later. The article analyses whether the economic crash actually led to a change in the parties' economic preferences and to a subsequent reformulation and adaptation of their long-term European policy goals and, if not, then how Iceland's decision to apply for EU membership is to be understood.

The following section provides an overview of Iceland's political and economic development since the crisis. Thereafter, the European policies of each of the country's political parties - the Social Democratic Alliance (SDA), the Left Green Movement (LGM), the Independence Party (IP), the Progressive Party (PP), the Liberal Party (LP) and the Citizens' Movement (CM) - will be analysed in detail. The investigation focuses on four related European issues that have been prominent in the Icelandic EU debate: an application to join the EU without reservations; the unilateral adoption of the euro; the inclusion of a clause in the constitution allowing a transfer of sovereignty; and the holding of a referendum on an EU application.

\section{Political and Economic Developments since the Financial Crisis}

At the beginning of 2008, the vulnerability of Iceland's financial sector and the inability of the state, as the lender of last resort, to save the banks should write-downs in the value of foreign assets place them in difficulty, became more evident (Central Bank of Iceland 2008a). The ISK fell drastically in March, indicating what was to come in terms of economic downturn and increased discussion about the adoption of another currency and EU membership. Under-estimation of the risk of a foreign currency shortage, and a subsequent lack of access to foreign currency, contributed significantly to the financial crisis (Guðmundsson 2009).

In the first week of October 2008, almost the entire Icelandic banking system collapsed, bringing the whole economy down with it and the ISK depreciated more than most small states' currencies. In early January 2008, the exchange rate had been ISK90 to the euro, but it lost value significantly in the following months. During that time the offshore rate of the ISK depreciated to ISK305 to the euro (European Central Bank 2008; Thomas 2008). The Central Bank of Iceland subsequently set capital controls on the 
currency, which are still in place. Backed up by these controls, the currency climbed back to ISK167 to the euro in January 2009 and ISK153 to the euro in August the following year (Central Bank of Iceland 2008b). The fall of the ISK has substantially increased the debt burden borne by those households and firms that had borrowed in foreign currencies. Moreover, the collapse of the overgrown financial sector, which had sought expansion abroad within the EEA framework, led to economic downsizing on a scale rarely before seen. In January 2009, inflation peaked at 18.6 percent and unemployment rose to over 9 percent - the highest level ever measured in Iceland (Central Bank of Iceland 2009). Iceland's GDP decreased by 6.8 percent in 2009, which was the largest drop ever recorded since measurements started in 1945 (Statistics Iceland 2010).

After weeks of violent protests (the most severe in Iceland's history) about how to tackle the economic crisis, the coalition government, consisting of the conservative Independence Party and the Social Democratic Alliance, collapsed in January 2009. A minority government, consisting of the SDA and the Left Green Movement (LGM), took over, with the tacit consent of the agrarian Progressive Party, while a general election was scheduled for the end of April 2009. The election saw the SDA and the LGM emerge victorious, and they subsequently formed the first majority left-wing government in Iceland's history.

The question of EU membership was soon sidelined by the Icesave dispute, which dominated Icelandic politics for a period of more than a year from early summer 2009 onward. Iceland had promised full reimbursement to the British and Dutch governments, which had compensated their citizens who had lost their investments in savings schemes operated by the Icelandic banks (Jóhannesson 2009). However, no formal agreement on reimbursement for the British and Dutch governments for their outlay to Icesave account holders in the Landsbanki bank has yet been made at the time of writing. This has had political repercussions: while Iceland struggled to obtain assistance from the International Monetary Fund (IMF), Britain and the Netherlands allegedly blocked such assistance on a number of occasions, with the formal and informal approval of other European states. A first settlement of the Icesave dispute, negotiated by the Icelandic government in May 2009, was heavily criticised and only narrowly approved by the Althingi in December 2009. The President of Iceland refused to ratify it, instead referring it to a referendum in which it was rejected by 93 percent of the votes cast. Due to this unresolved dispute, Iceland continues to face the possibility of a Dutch or British veto against its accession to the EU.

In July 2010, Iceland began formal accession talks with the EU - only twelve months after having submitted its application. However, due to the Icesave dispute, there has been an increase in nationalist feelings and the EU debate has largely focused on the question of whether or not Iceland 
should withdraw its application. In June 2010, MPs opposed to membership and belonging to all parties except the SDA proposed a motion to withdraw the EU application (Parliamentary Records 2009b). This move gained momentum during the summer months, but in the end it did not receive sufficient support from Left Green parliamentarians and the anti-European MPs in the opposition parties. Neither did another bill, proposed by seven parliamentarians who were still determined to halt the EU accession talks, to hold a referendum in November 2010 on whether or not to continue with the EU negotiations.

This shows that the government and the Althingi still stand by the application and favour the continuation of the accession talks. However, due to outspoken EU sceptics within the government's own ranks (from among the LGM), it has been severely damaged, both at home and in Brussels. For instance, half of the government's ministers - all from the LGM - have, up to the time of writing, opposed applying for and accepting EU grants within the framework of the EU's Instrument for Pre-Accession Assistance (IPA; Fréttablaðið 2010). Also, public opinion on EU membership has clearly been affected by the Icesave dispute. An opinion poll conducted in July 2010 indicated that 60 percent of voters were against membership, 26 percent were for it and 14 percent did not state an opinion (Capacent Gallup 2010). This represents a considerable drop in support compared to an opinion poll conducted two years earlier which showed that five out of ten voters were in favour of membership, three were against and two did not state an opinion (Capacent Gallup 2008a).

In addition, support for the EU membership negotiations has dropped considerably. In August 2010, about 45 percent were opposed to the negotiations, 39 percent in favour and 16 percent did not state an opinion (Vísir 2010a). This is a noticeable difference from the period from 1998 to early 2010 in which nearly all polls indicated a majority in favour of EU negotiations (e.g., see Capacent Gallup 2008b; Thorhallsson 2002). Accordingly, the pro-European forces have had a difficult time making their case in an atmosphere where Icelanders generally feel that all of their closest neighbouring states, except for the Faroe Islands, have deserted them in a time of great need. Although economic recovery appears to be under way in autumn 2010, 'it is still weak at present, and the outlook is for an output slack to remain for the next few years' (Central Bank of Iceland 2010b).

\section{The Political Parties' European Policies}

\section{Social Democrats Utilise the Opportunity}

The Social Democratic Party was the first political party in Iceland to advocate an EU application in 1994, more than thirty years later than the 
Social Democrats in Norway and Denmark. When the party merged with the socialist People's Alliance and the Women's Alliance in 1999 to form the Social Democratic Alliance (SDA), the question of EU membership was sidelined for a period of three years as the parties involved could not agree on a European policy (Thorhallsson 2004b). In 2002, the SDA adopted a pro-European policy, but refrained from campaigning actively on joining the EU in the following general elections (Thorhallsson 2004d). However, the financial crisis reconfirmed the position of the SDA, which had for a long time been the only party to argue that Iceland's economy would be better off within the EU than outside it (see Table 2). In fact, the crisis provided an unprecedented opportunity for the party to put EU membership on the political agenda. Thus, the SDA was able to justify breaking up its coalition with the Independence Party in January 2009 on the grounds that the latter did not adopt a pro-European policy (Fréttablaðið 2008a). Moreover, it was hopeful that its new coalition partner, the LGM, would not hinder a move towards an EU application (Morgunblaðið 2009a).

This hope was put to a first test in March 2009, when all parties represented in the Althingi - except for the Independence Party - introduced a proposal that envisaged four amendments to Iceland's constitution (Parliamentary Records 2009c). Although the Left Greens did not comply with the wishes of the SDA to put forward a proposal that would amend the national constitution to allow for a transfer of sovereignty to international organisations, one of the four proposed amendments would at least have facilitated amendments to the constitution so that only a referendum would have been needed for the amendments to come into effect. At present, amendments to the constitution can only come into effect through approval by the national parliament on two occasions: the dissolution of parliament and a general election in the interim. This would have meant a first step towards a possible EU application and opened up the possibility of a constitutional amendment on the transfer of sovereignty in the next parliamentary term (Visir 2009). However, the Independence Party managed to stall the debate so that the amendments were not approved before the forthcoming elections.

This seemed only a minor setback for the SDA, which continued to give prominence to its pro-European stance in its campaign before the general election of April 2009. It focused mainly on the potential economic benefits of membership and the adoption of the euro, aware of the fact that supporters of a closer engagement in the European project had won approval by emphasising economic benefits during the debates on both European Free Trade Area (EFTA) and EEA membership (Thorhallsson 2004a). Thus, the party's plan for economic recovery was based on EU membership (Social Democratic Alliance 2009), emphasising the benefits for consumers and enterprises of lower prices of goods, the adoption of the 
(C) 2011 The Author(s)

Scandinavian Political Studies () 2011 Nordic Political Science Association

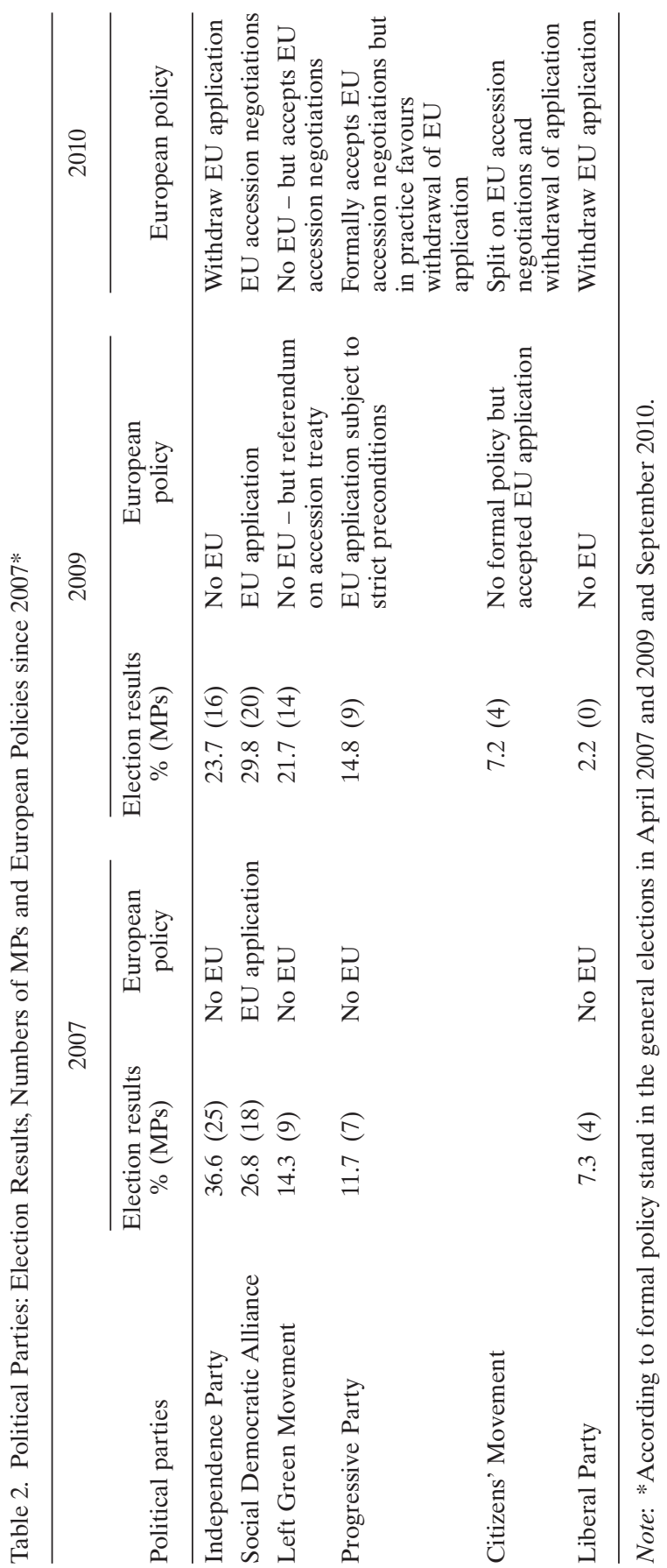


euro within the EU, and opportunities for aid for rural areas, agriculture and the tourist industry from the EU's Structural Funds. The party advocated an immediate EU application and rejected calls for a referendum on the application in addition to a referendum on the accession treaty (i.e., a 'double referendum') as well as the unilateral adoption of the euro. In order to achieve its goal, the SDA allied itself with influential interest groups, including the Federation of Trade and Services, the Federation of Icelandic Industries, the Icelandic Confederation of Labour, the Icelandic Travel Industry Association and the Icelandic Chamber of Commerce, and made a joint declaration with them, which was quoted in the report of the government committee that had been formed to assess attitudes in Iceland towards closer engagement in European integration (Prime Minister's Office 2009).

The general election rewarded the pro-European approach of the SDA, which became, for the first time, the largest political party (see Table 2). Also, the election results seemed to indicate a parliamentary majority in favour of an EU application, taking into account the new European policy of the Progressive Party and announcements made by the new parliamentarians of the Citizens' Movement in the election campaign. This, and the outlook for the first left-wing government in Iceland's history, strengthened the SDA's negotiating position and enabled it to make an EU application a precondition for forming a government with the EU-sceptic Left Green Movement. The coalition agreement between the two parties gave the Foreign Minister the authority to submit a bill on an EU application, approved by the government, to the Althingi. The agreement stated that the nation would decide in a referendum whether or not to join the EU on the merits of the prospective accession treaty. It also declared that the parties had different policies towards EU membership and would campaign for or against membership according to their respective policies (Government Ministries 2009).

However, since the application, the SDA has faced a difficult task in resisting repeated attempts by other parties, including its coalition partner, to withdraw the application. The changed political atmosphere since the Icesave debate has significantly reduced the momentum towards seeking EU membership. Nor does it help that pro-European economic interest groups such as the Federation of Icelandic Industries and the Federation of Trade and Services have remained relatively silent on the issue since their statements made prior to the EU application. Also, the Confederation of Icelandic Employers, whose corresponding organisations in the other Nordic states have been a driving force for EU membership, has not been active in the debate since a brief period in spring 2009 during which it advocated an EU application and the adoption of the euro. This is because of an outright split within it, where the powerful Federation of 
Icelandic Fishing Vessel Owners - the only major opponent of EU membership in the Confederation - is granted a blocking power on the EU question.

The financial crisis did not lead to a change in the economic preferences of the SDA. It had, for a long time, been of the opinion that EU membership would benefit Iceland economically. Nevertheless, the financial crash provided a short-term opportunity for the party to place the EU question on the political agenda and its strong negotiating position after the general election made it possible for it to carry the membership application through parliament.

\section{The Left Greens Open the Door to Accession Negotiations in Exchange for a Share in Government}

The Left Green Movement had campaigned fiercely against EU membership since its foundation and even called for an end to Iceland's membership of the EEA (Thorhallsson 2004b). However, after the financial crisis the party revised its European policy somewhat; this, at first sight, seemed to indicate that its economic preferences had changed (see Table 2). At its national conference in March 2009 it approached the pro-European policy of the SDA by stating that a democratic debate about the relationship between Iceland and the EU should take place and that membership should be decided in a single referendum following the negotiations (Left Green Movement 2009a). This approach met with severe criticism from EU opponents inside the party as it opened the possibility for the party's MPs to vote for the start of membership negotiations without a prior referendum. At the same time, however, the party confirmed its clear stance against EU membership, based mainly on its opposition to the transfer of sovereignty (Left Green Movement 2009b). Hence, the party line became somewhat blurred. Similar uncertainty surrounded the party's position on a possible change of currency. The LGM's election manifesto prior to the general election in April 2009 stated that Iceland's currency options should be examined in the first half of the next parliamentary term, with a decision to be made subsequently regarding the country's future currency (Left Green Movement 2009c).

In the general election, the LGM won a decisive victory, receiving 21.7 percent of the votes, up from 14.3 percent (see Table 2). Five of the movement's 14 newly elected MPs, including the Minister of Fisheries and Agriculture, bluntly rejected the European compromise between the coalition partners in government and stated that they would vote against the bill (Fréttablaðið 2009a). When the SDA foreign minister introduced the motion to the Althingi, these MPs campaigned against it vigorously. The remaining nine LGM MPs had a more difficult task in explaining their willingness to 
vote in favour of opening membership negotiations, while at the same time declaring their continued opposition to Iceland's EU accession, and incurred severe criticism from party members and the opposition. In the end, eight LGM MPs voted in support of the government proposal, while one abstained and five voted against it. Since the membership application, the Left Green ministers, except for one, and the majority of the party's MPs, have stood by the application and the accession talks. Nevertheless, a number of the party's MPs favour the withdrawal of the EU application, and one of them even chairs the anti-EU movement, Heimssýn.

Despite being divided on the issue of the EU application, the Left Green MPs have remained united in their rejection of Iceland's potential EU membership. As the party remains steadfast in its opposition to membership and firm on the sustainability of the ISK, its economic preferences have not been changed by the financial crisis. Its pragmatic willingness to accept an EU application seemed to have something to do with the economic crash and the weakening of the ISK, but even more with its eagerness, first, to split the coalition government of the IP and the SDA, and then to form a government with the latter. In fact, the LGM was ready to prioritise domestic concerns (i.e., participation in the first left-wing government in Iceland's history) over its European policy preferences. This reveals a major weakness in applying the theory of liberal intergovernmentalism to explain Iceland's European policy: the new government that applied for EU membership was able to do so without having a clear economic preference for membership. The LGM's leadership continues to tolerate the formal pro-European policy of the government led by the SDA only because of its firm belief that Iceland will not obtain a satisfactory accession treaty and that the treaty it is offered will be rejected in a referendum.

\section{The Independence Party Stumbles over the Quest for Accession}

From 1991 until January 2009, Iceland was governed by the Independence Party (IP), the most influential political party in the country, which has been in government for 52 of the 66 years since the foundation of the Icelandic Republic. The IP stifled all discussion of a possible application for EU membership in order to prevent an outright split in the party, despite considerable pressure at times from its changing coalition partners (see the detailed discussion in Thorhallsson 2008). Minority groupings consisting of individuals from the business community and the party's youth movement, who were willing to consider the membership alternative, were silenced by the powerful party leader and long-serving Prime Minister, Davíð Oddsson (1991-2004), who is a fierce opponent of EU membership (see Table 1). 
After the rapid fall in the value of the ISK in spring 2008, outright rejection of EU membership was no longer self-evident in the Independence Party, particularly on the grounds of currency considerations. Many EU supporters, mostly from the business segment of the party and therefore well placed to feel the constraints of the crumbling economy and constituting a powerful force within it, spoke out in favour of a proper debate within the party about EU membership. The party leadership reacted to this pressure by investigating the possibility of the unilateral adoption of another currency and specifically the euro, within the EEA framework (Bjarnason 2008). Since the start of the economic meltdown in early 2008, the unilateral adoption of another currency had considerable support within the party (Morgunblaðið 2009b).

After the economic crash, the leadership of the IP initiated a detailed examination within the party of the pros and cons of EU membership (Morgunblaðið 2008). While these initial moves signalled a gradual softening of the IP's firm opposition to EU membership, the party stuck to its traditional European policy in its special party conference in March 2009. The manifesto stated that 'EU membership did not serve the interests of the Icelandic nation', referring mainly to Iceland's sovereignty and independence and control of its natural resources (i.e., the issues of central interest to the fisheries and agrarian sectors) (Independence Party 2009a, 2009b, 2009c, 2009d). Yet, in order to reach out to pro-European elements within the party, the manifesto also claimed that many aspects of membership could only be clarified in formal negotiations with the EU and that the decision on whether or not to apply for EU membership should not be made by the political parties, but by the nation as a whole (Independence Party 2009a). If a future government or parliament came to the conclusion that Iceland should apply for EU membership, the IP's MPs should guarantee that this application would be subject to approval by a 'double referendum' (Independence Party 2009a). Thus, supporters agreed not to bring up the EU question on their own initiative, while opponents agreed not to oppose an EU application as a matter of principle, but to refer the decision to the Icelandic people.

Furthermore, the party's manifesto called for a review of the currency question and an immediate detailed examination (before the end of 2009) of the viability of the ISK and the possible adoption of another currency (Independence Party 2009e). The IP believed that the ISK would remain Iceland's currency for some time to come. However, it also stated that the euro was the most attractive part of the European project (Independence Party 2009c) and therefore pledged to fulfil the Maastricht criteria set for its adoption (Independence Party 2009e). Consequently, the economic collapse did not lead to a reformulation of the party's policy concerning EU membership (see Table 2), but it softened its attitude towards a possible adoption of the euro. 
One week before the elections, the IP made a last-minute attempt to reach out to its pro-European voters and proposed the adoption of the euro with the assistance of the IMF and the EU once the former's economic plan for Iceland had come to an end at the end of 2010 (Morgunblaðið 2009b). This idea was rejected in Brussels, though without the IP's advocates of the unilateral adoption of the euro giving up on it (Morgunblaðið 2009c). In the end, the IP suffered the worst election defeat in its history, receiving only 23.7 percent of the vote, down from 36.6 percent two years previously (Table 2).

When the left-wing government submitted the bill to apply for EU membership, the IP objected to it on two particular grounds. First, it maintained, in accordance with its party manifesto, that the decision to apply for EU membership should be subject to a 'double referendum', and second, it called for an amendment to the constitution before addressing the issue of EU membership since without such an amendment a referendum on the accession treaty would only be consultative and not binding (Parliamentary Records 2009d). In the end, the IP's proposed amendment to the bill was narrowly rejected. In the subsequent vote on the government proposal, only one of the IP's 16 MPs supported the EU application. The Eurosceptic party members had won the debate. This was confirmed at the party's annual conference in the summer of 2010, at which the Eurosceptics called for withdrawal of the EU application (Independence Party 2010). The party's chairman, Bjarni Benediktsson, even went as far as to state that the party would make the withdrawal of the application a precondition for forming a coalition government in the future (Baendablaðið 2010).

Thus, the financial crisis was not powerful enough to lead to a reversal of the economic preferences of the Independence Party. It only resulted in a temporary willingness of the party to take a more pragmatic stance, especially with regard to the adoption of the euro, and consider an EU application if it were subject to a 'double referendum' and constitutional changes. However, the financial crisis also ousted the IP from government, with the result that it was no longer in a position from which it could obstruct an application by Iceland for membership of the EU.

\section{The Contorted Policy of the Progressive Party}

In 2001, the Progressive Party (PP) dropped a clause in its party manifesto stating that it was against EU membership, adopting instead a 'wait and see' policy on the question (Thorhallsson 2004b). During its long time in government, the party leadership also kept discussion of EU issues going (e.g., by ordering governmental reports on Iceland and the EU), claiming that EU membership would better serve the country than the EEA Agreement 
(Ásgrímsson 2003) and suggesting that the government should consider the possibility of adopting the euro without joining the EU (Sverrisdóttir 2006). However, it did not raise the question of EU membership while holding the premiership from 2004 to 2006 (see Table 1).

At the end of 2007, the PP stated that it was open to discussing all options for a change of currency, whether this entailed the adoption of the euro or some form of currency cooperation with Norway and Switzerland (Fréttablaðið 2007). The party also adopted the 'double referendum' approach at its annual party convention in May 2008 as a response to growing pro-European pressure from within. Also, the party leadership emphasised that the constitution had to be revised to allow for a transfer of sovereignty to international organisations and to strengthen Iceland's negotiating position vis-à-vis the EU (Fréttablaðið 2008b).

When the financial crisis struck in autumn 2008, the PP overwhelmingly adopted a pro-European policy. Its party manifesto included a clause that Iceland should apply for EU membership subject to rigid preconditions, mainly in the fields of agriculture and fisheries (see Table 2). It no longer foresaw the need for a 'double referendum' on membership as long as these conditions were fulfilled (Progressive Party 2009). Moreover, the party stated that Iceland should seek a stabilisation agreement with the European Central Bank that would secure the stability of the ISK until it was possible for Iceland to adopt the euro (Progressive Party 2009), but that it should also continue to consider the possibility of adopting a new currency unilaterally.

Thus, the PP seemed, at first sight, to be the only Icelandic party to have changed its formal policy towards an EU application in connection with the economic crisis. However, the parliamentary debate on the EU application proved that this position remained highly contested, with the party MPs divided on how to interpret the results of its own convention. Ultimately, six MPs, including the party leader, voted against the government proposal for an EU application, while three voted for it. They were divided on the question of whether the proposal had taken sufficient account of the party's preconditions. Since then, despite the formal adoption of a pro-EU policy, the PP has remained split on the EU question, with the party leader and other MPs favouring the withdrawal of the application (Vísir 2010b). Hence, despite a formal policy change by the party, no actual change of preferences regarding closer engagement with Europe has taken place.

\section{The Liberal Party Takes an Anti-EU Course}

The small Liberal Party, originally a splinter group from the Independence Party, was formed in 1999 to campaign for a change in Iceland's fisheries policy and its quota system, and was reasonably open to the EU alternative 
as long as the interests of the fisheries sector were secured (Thorhallsson 2004b). However, in its election manifesto for the general election in 2009, the Liberal Party (2009a) expressed the position that Iceland should not enter into accession negotiations, but defend its sovereignty and find its own way out of the current crisis (see Table 2). The party's economic proposals added that Iceland should retain the ISK as the currency with which to rebuild its economy and not adopt the euro for the time being, although it admitted that the ISK was in a very weak condition (Liberal Party 2009b).

Thus, the Liberal Party became the only Icelandic party to be more opposed to European integration after the financial crisis than it had been before it. However, its anti-EU course was not rewarded and it suffered a landslide defeat in the general election, in which it lost all its four seats and dropped out of parliament after ten years' presence (see Table 2). One of its former MPs explained the wipe-out by the party's failure to alter its European policy as this had meant that it had not been an alternative for the pro-European voters of the IP. However, its internal quarrels and splits were likely to have played an important role as well (Fréttablaðið 2009b).

\section{The Citizens' Movement Hesitates}

Interestingly, the EU question was not addressed at all in the manifesto of the Citizens' Movement, which is an offspring of the protests following the financial crisis. The party stated, however, that a referendum should be held on international treaties that involved a transfer of sovereignty and that a new currency should be adopted, either by joining a currency union or by adopting another currency unilaterally (Citizens' Movement 2009a). The party's four MPs were expected to support an EU application (see Table 2), since at least two of them had openly spoken in favour of an application in the election campaign, with one of them stating that the Movement's policy was that negotiations with the EU would have to take place in order to decide whether or not to join the Union (Citizens' Movement 2009b).

However, in the midst of the EU debate in the Althingi, the Citizens' Movement suddenly changed its European policy. Having supported the left-wing government during the first EU parliamentary debate, the party decided during the second debate to align with the IP and to support the 'double referendum' approach. This move was motivated by the party's suspicion that Britain and the Netherlands would require Iceland's signature of the controversial Icesave settlement as some kind of admission ticket to EU membership (Parliamentary Records 2009e). Consequently, three Citizens' Movement MPs voted against the EU application, while one continued to support the government. 


\section{Conclusion}

This article has analysed whether the economic crash actually led to a change in the economic preferences of Iceland's political parties and to a subsequent reformulation and adaptation of their long-term European policy goals. Moravcsik's liberal theory of preference formation strongly suggests that a change of economic preferences must have taken place within Iceland's political parties after the financial crisis in order to make sense of the country's decision to apply for EU membership. However, the present analysis shows that the economic preferences of Iceland's political parties remained remarkably stable despite the EU membership application. The SDA continues to be the only party to support EU membership unanimously just as it did before the crisis, while the LGM and the IP still oppose membership, as does the Liberal Party and the majority of MPs in the PP and the Citizens' Movement. Also, the influential interest groups in the fisheries and agricultural sectors have not changed their position towards the question of EU membership and the Confederation of Icelandic Employers has again been silenced on the EU issue by the powerful fisheries lobby.

This is not to deny that some adjustments in the parties' policies towards the EU have taken place. Thus, the IP no longer objects to EU membership negotiations if accession is subject to a 'double referendum', and in principle it accepts an amendment to the constitution and the adoption of a new currency. In this approach it has been joined by the Citizens' Movement. Also, the LGM is willing to permit an EU application by its coalition partner - despite its own rejection of EU membership. Yet all these adjustments only concern the modalities of possible EU membership negotiations, not the question of EU membership per se. Even the Progressive Party, which adopted a policy proposal stating that Iceland should apply for membership with rigid preconditions, adopt the euro and amend the constitution, eventually disagreed internally on how these preconditions were to be interpreted. No actual change of preferences has taken place within the party since its leadership and the majority of its MPs have campaigned fiercely against the EU application ever since the general election of 2009.

The remarkable stability of the European policies of Iceland's political parties makes it impossible to account for the country's decision to apply for EU membership according to the theory of liberal intergovernmentalism. In fact, the case of Iceland seems to confirm existing criticism that the theory might be too simplistic to account for specific domestic circumstances (Wincott 1995). By focusing predominantly on economic preferences (and to a lesser degree on geopolitical concerns) to explain European policy, liberal intergovernmentalism tends to overlook factors such as the structure of domestic political institutions, the distribution of domestic political 
power and the degree of divided government, which are likely to impinge on national preference formation (Risse-Kappen 1996; Wallace et al. 1999) These domestic influences differ considerably from one European state to another and are unlikely to be satisfactorily covered in all cases by a general theory such as liberal intergovernmentalism.

Iceland's application for EU membership provides a good example of this. Although the economic crash did not lead to a change in the economic preferences of Iceland's political parties and to a subsequent reformulation of their European policy goals, it nevertheless opened a 'window of opportunity' on which pro-European forces were able to capitalise. The SDA suddenly found itself in a unique negotiating position vis-à-vis the LGM as there was a prospect of both a parliamentary majority in favour of an EU application and the first left-wing government in Iceland's history - a chance that the Left Greens were reluctant to miss. Thus, the SDA was able to press the Left Greens into accepting an EU application, even though the latter remained steadfast in their opposition to EU membership and have made this opposition perfectly clear ever since.

Thus, the case of Iceland shows that individual domestic circumstances can lead to significant changes in a state's European policy though macroeconomic preferences remain rather stable. This is a strong indication that domestic politics need to be thoroughly examined in order to understand a state's approach to EU integration. Attention must be given to matters such as those dealt with in this article: constitutional obstacles, proposed arrangements for referenda, the different currency options available, and political wheeling and dealing.

\section{REFERENCES}

Ásgrímsson, H. 2003. Hagsmunagaesla innan EES, 11 April 2003. Available online at: http:// www.utanrikisraduneyti.is/frettaefni/raedurHA/nr/1787.

Bergmann Einarsson, E. 2009. 'Hið huglaega sjálfstceði pjóðarinnar': Áhrif pjóðernishugmynda á Evrópustefnu íslenskra stjórnvalda. Reykjavík: Háskóli Íslands.

Bjarnason, B. 2008. 'Evruaðild - Guðnaráo - Nýfrjálshyggja', 12 July. Available online at: http://www.bjorn.is/pistlar/2008/07/12/nr/4538.

Bandablaðið. 2010. 'Sjálfstæðisflokkurinn nú sem fyrr andsnúinn ESB-aðild', 8 June. Available online at: http://www.bondi.is/lisalib/getfile.aspx?itemid=2892.

Capacent Gallup. 2008a. Viðhorfs almennings til ESB, August. Available online at: http:// www.si.is/media/althjodlegt-samstarf/2008-08-ESB-almenningur.pdf.

Capacent Gallup. 2008b. Próun viðhorfs almennings til ESB frá ágúst 2000 til ágúst 2008, September. Available online at: http://www.si.is/media/althjodlegt-samstarf/2008-ESBalmenningur-samatekt-2000-2008.pdf.

Capacent Gallup. 2009. Viðhorf almennings til ESB, February. Available online at: http:// www.si.is/media/althjodlegt-samstarf/2009-02-ESB-almenningur.pdf.

Capacent Gallup. 2010. Viðhorf til Evrópusambandsaðildar Íslands, July. Available online at: http://capacent.is/Frettir-og-frodleikur/Thjodarpulsinn/Thjodarpulsinn/2010/07/06/Vidhorftil-Evropusambandsadildar-Islands/.

Central Bank of Iceland [Seðlabanki Íslands]. 2008a. Fundir í London í febrúar 2008, Memorandum, 12 February. 
Central Bank of Iceland [Seðlabanki Íslands]. 2008b. Peningamál 34, November. Available online at: http://sedlabanki.is/lisalib/getfile.aspx?itemid=6679.

Central Bank of Iceland [Seðlabanki Islands]. 2009. Peningamál 35, January. Available online at: http://english.sedlabanki.is/lisalib/getfile.aspx?itemid=6764.

Central Bank of Iceland [Seðlabanki Íslands]. 2010a. Information from the Chief Economist and Director of Economics Department at the Central Bank of Iceland, 18 January.

Central Bank of Iceland [Seðlabanki Íslands]. 2010b. Monetary Policy Committee Report to Alpingi, 1 September. Available online at: http://www.sedlabanki.is/lisalib/getfile.aspx? itemid $=8078$.

Citizens' Movement [Borgarahreyfingin]. 2009a. Stefnan - Policy. Available online at: http:// www.borgarahreyfingin.is/gamla/stefnan/.

Citizens' Movement [Borgarahreyfingin]. 2009b. 'Pór Saari: ESB og kjarkleysið', 24 April. Available at: http://www.borgarahreyfingin.is/gamla/2009/04/24/thor-saari-esb-ogkjarkleysid/.

European Central Bank. 2008. 'Icelandic króna - Latest rate 3 Dec 08 (ISK)'. Available online at: http://www.ecb.int/stats/exchange/eurofxref/html/eurofxref-graph-isk.en.html.

Fréttablaðið. 2007. 'Parf að ræða alla möguleika', 29 December. Available online at: http:// epaper.visir.is/media/200712290000/pdf_online/1_2.pdf.

Fréttablaðið. 2008a. 'Samfylkingin bíður Sjálfstæðisflokksins', 27 December. Available online at: http://epaper.visir.is/media/200812270000/pdf_online/1_2.pdf.

Fréttablaðið. 2008b. 'Breytingar á stjórnarskrá aðkallandi', 4 May. Available online at: http:// epaper.visir.is/media/200805040000/pdf_online/1_6.pdf.

Fréttablaðið. 2009a. 'Fimm pingmenn VG ætla að vera á mótí', 11 May. Available online at: http://epaper.visir.is/media/200905110000/pdf_online/1_1.pdf.

Fréttablaðið. 2009b. 'Saga Frjálslyndra er saga deilna og átaka', 28 April. Available online at: http://epaper.visir.is/media/200904280000/pdf_online/1_10.pdf.

Fréttablaðið. 2010. 'Vilja ekki styrki frá Evrópusambandinu', 19 October. Available online at: http://epaper.visir.is/media/201010190000/pdf_online/1_1.pdf.

Government Ministries [Stjórnarrád Íslands]. 2009. Samstarfsyfirlýsing ríkisstjórnar Samfylkingarinnar og Vinstrihreyfingarinnar graens framboðs: Utanríkis- og Evrópumál. Available online at: http://www.stjornarrad.is/Stefnuyfirlysing/\#Utanrikis-_og_Evropumal.

Guðmundsson, M. 2009. 'Hin alpjóðlega fjármálakreppa: Rætur og viðbrögð', in Guðmundsson, H., ed. Skírnir: Tímarit hins íslenska bókmenntafélags. Reykjavík: Hið̌ íslenska bókmenntafélag.

Hálfdanarson, G. 2004. 'Discussing Europe: Icelandic Nationalism and European Integration', in Thorhallsson, B., ed., Iceland and European Integration: On the Edge. London: Routledge.

Handel, M. 1981. Weak States in the International System. London: Frank Cass.

Independence Party [Sjálfstæðisflokkurinn]. 2009a. Ályktun um Evrópumál. Available online at: http://xd.is/?action=landsfundur_2009_nanar\&id=1007.

Independence Party [Sjálfstæðisflokkurinn]. 2009b. Ályktun um utanríkismál. Available online at: http://xd.is/?action=landsfundur_2009_nanar\&id=917.

Independence Party [Sjálfstæðisflokkurinn]. 2009c. Alyktun endurreisnarnefndar. Available online at: http://xd.is/?action=landsfundur_2009_nanar\&id=1008.

Independence Party [Sjálfstæðisflokkurinn]. 2009d. Skýrsla Evrópunefndar. Available online at: http://media.evropunefnd.is/u/d/evropuskyrslan.pdf.

Independence Party [Sjálfstæðisflokkurinn]. 2009e. Ályktun um efnahags- og skattamál. Available online at: http://xd.is/?action=landsfundur_2009_nanar\&id=908.

Independence Party [Sjálfstæðisflokkurinn]. 2010. Frelsi-Ábyrgð - Umhyggja: 39. Landsfundur Sjálfstceðisflokksins 25. og 26. júní 2010. Available online at: http://www.xd.is/media/ landsfundur/stjornmalaalyktun_endanleg.pdf.

Ingebritsen, C. 1998. The Nordic States and European Unity. Ithaca, NY: Cornell University Press.

Jóhannesson, G. T. 2009. Hrunið, Ísland á barmi gjaldprots og upplausnar. Reykjavik: JPV útgáfa.

Kristinsson, G. H. \& Thorhallsson, B. 2004. 'The Euro-sceptical Political Elite', in Thorhallsson, B., ed., Iceland and European Integration: On the Edge. London: Routledge. 
Left Green Movement [Vinstrihreyfingin-Grænt framboð]. 2009a. Ályktanir sampykktar á Landsfundi Vinstrihreyfingarinnar - graens framboðs. Reykjavík, 20. - 22. mars 2009. Available online at: http://www.vg.is/media/myndir/landsfundur/Alyktanir_landsfundar_VG_ 2009_-_lokid.doc.

Left Green Movement [Vinstrihreyfingin-Grænt framboð]. 2009b. Stefnan. Available online at: http://www.vg.is/stefna/.

Left Green Movement [Vinstrihreyfingin-Grænt framboð]. 2009c. Vegur til framtíðar. Áherslur Vinstri granna í lýdræeðis-, velferðar-, atvinnu- og efnahagsmálum sampykktar á landsfundi í mars 2009. Available online at: http://www.vg.is/stefna/malefni/.

Liberal Party [Frjálslyndi flokkurinn]. 2009a. Stjórnmálayfirlýsing Frjálslynda flokksins, 19. og 20. mars 2009. Available online at: $h t t p: / / x f$.is/index.php?option=com_content\&view= article \&id=26\&Itemid $=27$.

Liberal Party [Frjálslyndi flokkurinn]. 2009b. Helstu tillögur og áherslur Frjálslynda flokksins $i$ efnahags- og atvinnumálum. Available online at: http://xf.is/pages/efnahags-og-atvinnumal$2009 /$.

Moravcsik, A. 1993. 'Preference and Power in the European Community: A Liberal Governmentalist Approach', Journal of Common Market Studies, 31, 473-524.

Moravcsik, A. 1998. The Choice for Europe: Social Purpose and State Power from Messina to Maastricht. Ithaca, NY: Cornell University Press.

Morgunblaðið. 2008. 'Skipuð verði Evrópunefnd', 14 November. Available online at: http:// $\mathrm{mbl}$.is/mm/frettir/innlent/2008/11/14/skipud_verdi_evropunefnd/.

Morgunblaðið. 2009a. 'Evrópumálið hefur forgang', 27 April. Available online at: http://mbl.is/ mm/frettir/innlent/2009/04/27/evropumalid_sett_i_forgang/.

Morgunblaðið. 2009b. 'Vilja upptöku Evru í samvinnu við AGS', 18 April. Available online at: http://mbl.is/mm/frettir/kosningar/2009/04/18/vilja_upptoku_evru_i_samvinnu_vid_ags/.

Morgunblaðið. 2009c. 'AGS getur ekki haft milligöngu um upptöku evru', 20 April. Available online at: http://mbl.is/mm/frettir/kosningar/2009/04/20/ags_getur_ekki_haft_milligongu/.

Parliamentary Records [Vefútgáfa Alpingistíðinda]. 2009a. Atkvaððagreiðsla, pskj. 38, 38. mál, 16 July. Available online at: http://www.althingi.is/dba-bin/atkvgr.pl?nnafnak=41080.

Parliamentary Records [Vefútgáfa Alpingistíðinda]. 2009b. Tillaga til pingsályktunar um að draga til baka umsókn Íslands um aðild að Evrópusambandinu, pskj. 1337, 669. mál, 14 June. Available online at: http://www.althingi.is/altext/138/s/1337.html.

Parliamentary Records [Vefútgáfa Alpingistíðinda]. 2009c. Frumvarp til stjórnarskipunarlaga, pskj. 648, 385. mál, 3 March. Available online at: http://www.althingi.is/altext/136/s/0648.html.

Parliamentary Records [Vefútgáfa Alpingistíðinda]. 2009d. Nefndarálit um tillögu til pyngsályktunar um aðildarumsókn að Evrópusambandinu frá 1. minni hluta utanríkismálanefndar, pskj. 255, 38. mál, 10 July. Available online at: http://www.althingi.is/altext/137/s/0255.html.

Parliamentary Records [Vefútgáfa Alpingistíðinda]. 2009e. 16 July 2010. Available online at: http://www.althingi.is/altext/raeda/137/rad20090716T110241.html.

Prime Minister's Office [Forsætisráðuneytið]. 2009. Skýrsla nefndar um próun Evrópumála. Available online at: http://evropumal.forsaetisraduneyti.is/media/Skyrslur/2009-17-4skyrsla-nefndar-um-throun-evropumala.pdf.

Progressive Party [Framsóknarflokkurinn]. 2009. Ályktanir 30. flokkspings framsóknarmanna 16.-18. janúar 2009. Available online at: http://www.framsokn.is/files/3948-0.pdf.

Risse-Kappen, T. 1996. 'Exploring the Nature of the Beast: International Relations Theory and Comparative Policy Analysis Meet the European Union', Journal of Common Market Studies, 34(1), 54-81.

Social Democratic Alliance [Samfylkingin]. 2009. Stjórnmálaályktun. Available online at: http:// www.samfylkingin.is/Stefnum \%C3\%A11/Sam\%C3\%BEykktir_landsfundar.

Statistics Iceland [Hagstofa Íslands]. 2009. Framleiðsluuppgjör. Available online at: http:// hagstofan.is/?PageID=758\&src=/temp/Dialog/varval.asp?ma=THJ08101\%26ti=Hlutur+ atvinnugreina+\%ED+landsframlei\%F0slu+1973\%2D2008+\%26path=../Database/ thjodhagsreikningar/framluppgj_ISAT01/\%26lang=3\%26units=Hlutfall.

Statistics Iceland [Hagstofa Íslands]. 2010. Lykiltölur. Available online at: http://hagstofa.is/ Pages/1374.

Sverrisdóttir, V. 2006. 'Ísland og Evran', 8 March. Available online at: http://www.valgerdur.is/ index.php?pid=20\&cid=524. 
Thomas, C. 2008. 'Icelandic Shoppers Splurge as Currency Woes Reduce Food Imports', Bloomberg, 13 October. Available online at: http://www.bloomberg.com/apps/news?pid= newsarchive\&sid=aVFtDRGwcc50\&refer=home\&refer=europe.

Thorhallsson, B. 2002. 'The Sceptical Political Elite versus the Pro-European Public: The Case of Iceland', Scandinavian Studies, 74(3), 349-78.

Thorhallsson, B., ed.,2004a. Iceland and European Integration: On the Edge. London: Routledge.

Thorhallsson, B. 2004b. 'Approaching the Question: Domestic Background and Conceptual Framework', in Iceland and European Integration: On the Edge. London: Routledge.

Thorhallsson, B. 2004c. 'Partial Engagement: A Practical Solution', in Iceland and European Integration: On the Edge. London: Routledge.

Thorhallsson, B. 2004d. 'Towards a New Theoretical Approach', in Iceland and European Integration: On the Edge. London: Routledge.

Thorhallsson, B. 2008. 'Evrópustefna íslenskra stjórnvalda: Stefnumótun, átök og afleiðingar', in Ingimundarson, V., ed., Uppbrot hugmyndakerfis: Endurmótun íslenskrar utanríkisstefnu 1991-2007. Reykjavik: Hið íslenska bókmenntafélag.

Vísir. 2009. 'Stjórnarskrá breytt fyrir ESB-aðild', 4 February. Available online at: http:/l www.visir.is/article/200938564492.

Vísir. 2010a. 'Fleiri styðja viðræður við ESB', 2 September. Available online at: http:// epaper.visir.is/media/201009020000/pdf_online/1_2.pdf.

Vísir. 2010b. 'Vilja draga umsókn til baka', 15 June. Available online at: http://www.visir.is/viljadraga-umsokn-til-baka/article/2010394487748.

Wallace, H., Caporaso, J. A., Schampf, F. W. \& Moravcsik, A. 1999. 'Review Section Symposium. The Choice for Europe: Social Purpose and State Power from Messina to Maastricht', Journal of European Public Policy, 6(1), 155-79.

Wincott, D. 1995. 'Institutional Interaction and European Integration: Towards an Everyday Critique of Liberal Intergovernmentalism', Journal of Common Market Studies, 33(4), 597609. 